\title{
Correction to: Hsa_circ_0001361 facilitates the progress of lung adenocarcinoma cells via targeting miR-525-5p/VMA21 axis
}

Hong-Yu Shen ${ }^{1}$, Liu-Xi Shi ${ }^{2+}$, Lin Wang ${ }^{1+}$, Le-Ping Fang ${ }^{1}$, Wei Xu' ${ }^{1}$ Ju-Qing Xu', Bo-Qiang Fan ${ }^{3 *+}$ and Wei-Fei $\operatorname{Fan}^{1 *+}$ (10)

\section{Correction to: J Transl Med (2021) 19:389}

https://doi.org/10.1186/s12967-021-03045-4

Following publication of the original article [1], the authors identified an error in the order of e-mail addresses.

The original publication lists the contacts as followed:

*Correspondence: bq_fan@139.com;

fwfei1974@njmu.edu.cn.

However, the correct order of contacts is:

"Correspondence: fwfei1974@njmu.edu.cn; bq_fan@139.com.

This is due to Dr. Fan being the main corresponding author.

The original article has been updated to reflect the correct order.

\begin{abstract}
Author details
'Department of Hematology and Oncology, Department of Geriatric Lung Cancer Laboratory, Geriatric Hospital of Nanjing Medical University, Jiangsu Province Geriatric Hospital, No.65 Jiangsu Road, Gulou District, Nanjing 210000, Jiangsu, People's Republic of China. ${ }^{2}$ GCP Office, The Second Affiliated Hospital of Soochow University, Suzhou 215000, Jiangsu, People's Republic of China. ${ }^{3}$ Department of Oncology, The First Affiliated Hospital of Nanjing Medical University, Nanjing 210000, Jiangsu, People's Republic of China.
\end{abstract}

Published online: 25 November 2021

\section{Reference}

1. Shen HY, Shi LX, Wang L,Fang LP, Xu W, Xu JQ, Fan BQ, Fan WF. Hsa_ circ_0001361 facilitates the progress of lung adenocarcinoma cells via targeting miR-525-5p/VMA21 axis. J Transl Med. 2021;19:389. https://doi. org/10.1186/s12967-021-03045-4

\section{Publisher's Note}

Springer Nature remains neutral with regard to jurisdictional claims in published maps and institutional affiliations.

The original article can be found online at https://doi.org/10.1186/s12967021-03045-4.

\footnotetext{
*Correspondence: fwfei1974@njmu.edu.cn; bq_fan@139.com

${ }^{\dagger}$ Liu-Xi Shi and Lin Wang are co-first authors

${ }^{\dagger}$ Bo-Qiang Fan and Wei-Fei Fanare Co-corresponding authors

${ }^{1}$ Department of Hematology and Oncology, Department of Geriatric Lung Cancer Laboratory, Geriatric Hospital of Nanjing Medical University, Jiangsu Province Geriatric Hospital, No.65 Jiangsu Road, Gulou District, Nanjing 210000, Jiangsu, People's Republic of China

${ }^{3}$ Department of Oncology, The First Affiliated Hospital of Nanjing Medical University, Nanjing 210000, Jiangsu, People's Republic of China

Full list of author information is available at the end of the article
} permits use, sharing, adaptation, distribution and reproduction in any medium or format, as long as you give appropriate credit to the original author(s) and the source, provide a link to the Creative Commons licence, and indicate if changes were made. The images or other third party material in this article are included in the article's Creative Commons licence, unless indicated otherwise in a credit line to the material. If material is not included in the article's Creative Commons licence and your intended use is not permitted by statutory regulation or exceeds the permitted use, you will need to obtain permission directly from the copyright holder. To view a copy of this licence, visit http://creativecommons.org/licenses/by/4.0/. The Creative Commons Public Domain Dedication waiver (http://creativecommons.org/publicdomain/zero/1.0/) applies to the data made available in this article, unless otherwise stated in a credit line to the data. 